\title{
HOW DOES THE FIRM SIZE AFFECT THE RELATIVE IMPORTANCE OF COUNTRY AND INDUSTRY EFFECT IN CAPITAL STRUCTURE? EMPIRICAL EVIDENCE FROM EUROPE
}

The purpose of this study is to determine the relative importance of the country and industry factors in the capital structure depending on the firm size. The analysis includes three size groups of firms in thirteen industries of nine EU countries and covers the period 2000-2009. The applied methods include multivariate statistical analysis, mainly the $k$-means cluster analysis. Findings reveal the prevalence of the country factors, although not homogeneously across all size groups.

Keywords: capital structure, country effect, industry effect, firm size

JEL classifications: G32

DOI: $10.15611 /$ aoe.2017.1.04

\section{INTRODUCTION}

The interest in factors affecting corporate capital structure is widely reflected both in the theoretical literature and empirical research aiming to verify the significance of individual determinants of debt. Comparing the impact of the country and industry factors on the capital structure, i.e. identifying the country and industry effect and their relative importance, is also not a novelty in the financial literature. However, to the author's knowledge, so far no attempt has been made to compare the impact of these two effects, depending on the firm's size, although the latter factor itself has been thoroughly examined in the context of capital structure. This study aims to fill this gap for the selected EU countries.

Since the company size significantly affects its financing choices, it can be expected that this feature may also affect the way other capital structure determinants impact on decisions concerning financing. The considerable qualitative differences between firms of different sizes can potentially differentiate the relative importance of capital structure factors across individual size groups, which is the main hypothesis to be verified in this study.

\footnotetext{
* University of Gdańsk, Faculty of Management, Department of Corporate Finance, Gdańsk
} 


\section{THE ROLE OF COUNTRY, INDUSTRY AND FIRM SIZE SPECIFICITY IN CAPITAL STRUCTURE - LITERATURE REVIEW}

The starting point for the modern capital structure theories is the study by Modigliani and Miller (1958), which states that under certain assumptions the firm's financial decisions are irrelevant in terms of the firm value. The basic assumptions of the MM theory refer to the absence of taxes, transaction costs and bankruptcy risk (Titman 2001). Other frequently mentioned limitations include the same risk class of all companies, the full symmetry of information between internal and external investors or managers' loyalty to the owners (Frydenberg 2004). This breakthrough theory of irrelevance has given rise to a number of attempts to verify whether the capital structure is in fact relevant, and under what conditions (Song 2005).

The hitherto empirical research shows that the company's capital structure is not only influenced by firm-specific factors, but also by the specificity of the country where a company operates (Demirgüç-Kunt, Maksimovic 1999; Booth, Demirgüç-Kunt, Maksimovic 2001; Claessens, Djankov, Nenova 2001; Bancel, Mittoo 2004). Moreover, it has been empirically shown that country factors influence financial leverage in two ways (De Jong, Nguyen, Kabir 2008). On the one hand, these factors impact on the leverage directly. For example, a more developed bond market facilitates the issuance and trading of debt securities, and as a result it can lead to higher levels of corporate debt in a given country, whereas in the mature equity market - the opposite. On the other hand, factors specific to the country also have an indirect effect on corporate debt through their influence on factors specific to the companies themselves.

One of the first international studies comparing differences in capital structure across developed and industrialized countries reveals that apart from business-specific factors, some domestic factors play an important role in affecting capital structure (Rajan, Zingales 1995). Another international comparative study (Demirgüç-Kunt, Maksimovic 1999) of corporate capital structure, also shows that institutional differences between developed and developing countries explain a large part of the diversification of long-term debt. It has also been observed that some institutional factors in developing countries affect the leverage differently depending on the firm size. More recent studies in this area show that even in developed economies, such as European countries or the United States, the financial policy and the 
behaviour of managers are influenced by institutional envirionment and international transactions (Graham, Harvey, 2001; Bancel, Mittoo 2004; Brounen, De Jong, Koedijk 2006). The importance of country factors in terms of capital structure was also recognized by Fan et al. (2006) in a crosssectional study of a large sample of countries which confirms the significant influence of such factors as the development of the banking sector and the stock and bond markets. Another survey of the OECD countries shows that most of the capital structure volatility in an international cross-section is attributed to the heterogeneity of firm-specific factors, industry and country factors (Song, Philippatos 2004). However, the authors found no evidence on the importance of the diversity of legal factors in terms of leverage. This may be due to the fact that a lot of research covers only large listed companies (Giannetti 2003). However, even the less common studies of nonpublic firms confirm the significant impact on capital structure of such variables as the protection of creditors, the securities market development and law enforcement (Hall et al. 2004). The country factors also include such variables as the banking system orientation and the gross domestic product growth rate (De Jong et al. 2008).

Another determinant of leverage covered in this study is the industrial specificity which - as shown by numerous studies on the capital structure is also considered as one of the key factors affecting corporate financial decisions (Bradley et al., 1984; Titman, Wessels 1988; Rajan, Zingales 1995; Harris, Raviv 1991). According to the leading theories of capital structure (Almazan, Molina 2002), the main factors responsible for industrial differences in leverage between companies include: the level of competition in the industry (Liebenstein 1966), the extent of employing managerial mechanisms to resolve agency conflicts by firms (Jansen, Meckling 1976), the flexibility of assets (Shleifer, Vishny 1992), and the technological differences between firms in industries (Maksimovic, Zechner 1991).

Among many capital structure determinants, the size of the firm seems a factor less exposed in the studies verifying individual theories. Nevertheless, some empirical studies show a strong positive relationship between the size of a company and the leverage ratio (Kurshev et al., 2007). The results of these studies are unambiguous for the the United States, where large companies tend to have higher debt ratios than small ones (Titman, Wessels 1988; Rajan, Zingales 1995, Fama, French 2002). In most other countries the size of the company also appeared to have a positive relationship with debt (Rajan, Zingales 1995, Booth et al. 2001). 
Intuitively, the size effect can be explained in various ways. First of all, large companies tend to have easier access to external funds as borrowing costs are much higher for small businesses than for large ones (Hennessy, Whited 2006). Large companies are also believed to be less likely to go bankrupt (Shumway 2001). Another explanation is the difference in the degree of information asymmetry between the firm's insiders and capital markets, which is usually less acute for larger firms (Kurshev, Strebulaev, Ilya 2007).

The literature review makes it clear that both country and industry factors are important determinants of the corporate capital structure. A common research problem in this area is the relative importance of these two categories of factors. Some earlier attempts to prioritise the importance of the country effect and the industry effect in the European Union reveal that despite the significant progress of the integration processes in the area, indicating a higher probability of reducing the differences between countries, the capital structure of companies and other long-term solvency parameters are still more influenced by country factors than by industrial ones (KoralunBereźnicka 2009). The analysis, however, did not not take into account the size of businesses. Given the fact that company size impacts on its financial structure, it is also possible that the relative importance of the country and industry effect will vary between size groups. The main research goal of this study is therefore to determine the relative importance of the country factors and the industry factors in the capital structure of enterprises depending on their size.

\section{DATA CHARACTERISTICS AND RESEARCH METHODOLOGY}

The concept of capital structure and the related terms, such as financial structure, financial leverage or gearing, can be defined as a combination of different types of securities issued by a company to finance its assets. A company financed with equity only is referred to as unleveraged, whereas a company which uses debt in its financial structure is a leveraged company (Song 2005).

In this study the capital structure is the dependent variable. There is, however, a variety of measures of capital structure, which can be broadly divided into two main groups: measures based on the market value of equity and measures based on the book value of equity (Lööf 2003). Due to the limited data availability, some empirical studies often have to be restricted to the use of financial leverage ratios based solely on book values. This is also 
the case in this research, where the market values are not available, as the analysed population covers private firms.

The choice of the most suitable measure of capital structure should depend on the purpose of the analysis. However, the results of corporate financial decisions are probably best represented by the ratio of total debt to total capital, defined as the sum of shareholders' equity and total debt (Rajan, Zingales 1995). In each case, therefore, when interpreting the research results one should be aware of the difficulties with measuring both leverage and the explanatory variables (Harris, Raviv 1991). The problems with measuring capital structure may result for example in the sensitivity of the analytical results to the changes in measures of debt. According to a survey of British companies, the determinants of capital structure differ significantly depending on which component of debt is taken into account (Bezan, Danbolt 2000). The differences are the most significant with reference to the factors of short-term and long-term debt.

Therefore a comprehensive analysis of the capital structure requires considering various forms of debt. With this in mind, this study takes into account not only the most commonly recommended ratio of total debt to total assets, but also a number of more specific ratios describing the structure of liabilities, representing the share of the following items in the total assets:

- $\operatorname{debt}(\mathrm{D} / \mathrm{A})$,

- provisions $(\mathrm{P} / \mathrm{A})$,

- bank credits (C/A),

- medium- and long-term bank credits (LC/A),

- short-term bank credits (SC/A),

- medium- and long-term liabilities (LL/A),

- short-term liabilities (SL/A).

The selection of ratios also results from the content of the BACH (Bank for the Accounts of Companies Harmonised) database, which does not provide market values due to the aforementioned reasons. The variables are the ratios of means, and not the means of ratios, as the data provided by the database is aggregated. The study covers nine European Union countries (Austria, Belgium, Germany, Spain, France, Italy, the Netherlands, Poland and Portugal), providing data to the European Commission, which publishes them as aggregated and harmonised reports in the BACH database. The choice of the research sample in terms of countries is also conditioned by the data availability in the employed database. The study covers all the countries which provide data from the annual accounts of non-financial firms. Relying on data from one source provides the highest achievable level of cross- 
country comparability of ratios, although covering a wider group of countries in the future would certainly be valuable.

The analysis covers three groups of companies: small (with an annual turnover below 10 million EUR), medium (with an annual turnover between 10 and 50 million EUR) and large (with an annual turnover exceeding 50 million EUR) in thirteen economic industries represented by one-letter symbols (section level) according to the NACE classification (Nomenclature statistique des Activités économiques dans la Communauté Européenne). Some industries were excluded from the analysis due to the limited data availability. Table 1 provides the detailed list of the industrial range of the study and the three-letter symbols assigned to each industry, which are used later in the study. The study period covers the decade 2000-2009. The groups of companies ordered by country, size, industry and year constitute the subject of the analysis.

All the ratios used in the analysis were calculated for the aggregated groups of companies in each industry, each size group (indicated by the letters S, M and L, respectively), each country and each year. In total, taking into account the missing data, the analysis covers 20,869 data items.

The first stage of the empirical research is the basic statistics analysis of financial ratios in the following cross-sections: across industries, across countries, across size groups and across time. It is aimed to initially recognize the diversity of ratios and identify the basic regularities within the analysed population. In cases of differences in means between individual categories, it should be verified whether they are statistically significant. For this purpose the one-way analysis of variance was applied which allows to evaluate the significance of differences between a number of means and explains the probability with which the extracted grouping factors (manipulative variables) could be the reason for the observed differences between the group means (Fisher 1954).

In order to verify which effect is the dominant one - the country or industry effect - the cluster analysis was used to classify the binomial objects formed by industries in countries. Due to the large number of the classified objects, the $k$-means algorithm was applied as a grouping method whose goal is to create $k$ different, possibly distinct clusters formed in a way which minimises the within-group variance while maximising the betweengroup variance (Wishart 2001). If the objects had a tendency to form clusters in a manner similar to the national classification, it would indicate the superiority of the country effect. The dominance of the industry effect would be indicated by the clustering results resembling industrial classification. 
The classification results usually make it possible to identify the dominant element in the form of a country or an industry in each of the clusters. The prevalence of clusters dominated by countries would indicate the greater impact of domestic factors on the examined variables describing capital structure. The industrial nature of clusters would suggest the greater similarity of objects in the cross-industry section rather than across countries, which would indicate the stronger influence of industrial factors.

The $k$-means procedure was performed for all size groups of firms as a total and then for each of them individually, in order to detect the possible differences in the relevant importance of the two effects. When carrying out the cluster analysis separately for small, medium and large businesses, an important issue is to assess the differentiation degree of the grouping results, i.e. to compare the clustering results and evaluate their similarity. In order to find out how similar or how different the clusters of industries in countries are between different size groups, a similarity measure of grouping results can be utilised. From the variety of grouping results similarity measures proposed in the literature (Gordon, 1987; Arabie, Boorman 1973; Fowkles, Mallows 1983; Goodman, Kruskal 1980; Rand 1971; Rolf 1974; Wallace $1983)$, one of the most commonly used is the adjusted Rand measure $\left(R_{A D}\right)$, which was also applied in this study. Higher $R_{A D}$ values indicate greater similarity of the compared grouping results. The calculation method of the measure is provided for example by Hubert and Arabie (1985) or Najman (2007).

\section{RESEARCH RESULTS}

The first stage of the analysis was meant to examine whether the differences in capital structure ratios are statistically significant across industries, countries, size groups and years. For this purpose the one-way analysis of variance was performed in the four sections corresponding to the dimensions of the data. The discriminating properties of ratios were evaluated on the basis of the F-statistic whose values and the corresponding probabilities $p$ are shown in Table 2. The cases for which the null hypothesis of equal means was rejected are distinguished by putting in bold the respective values.

The results of the univariate significance tests show that all the analyzed capital structure ratios differ significantly both across countries as well as across industries. However, if the firm size is the differentiating factor, the ratio of debt to asset appears not to differ significantly between the size 
groups, in contrast to all other capital structure ratios. Only four variables show significant differences across time in the analysed period, which indicates the weakest discriminatory power of the time factor in the examined population. This, in turn, is the reason for performing the following stages of the analysis using the time means of ratios, which can be considered as values representing typical levels of variables for the entire ten-year period.

The diagnostic variables used in the cluster analysis should be characterised by high volatility and independence. This means that the variables which do not differentiate between the categories (industries and countries) should be removed from the initial data set. The cases of duplicating the information carried by individual variables should also be eliminated. According to the analysis of variance, none of the selected variables is a constant one. As for the interdependence of variables, several of them were eliminated due to the correlation coefficient exceeding the value of 0.6. As a result, the final set of diagnostic variables included four ratios: $\mathrm{D} / \mathrm{A}, \mathrm{P} / \mathrm{A}, \mathrm{LC} / \mathrm{A}$ and $\mathrm{SL} / \mathrm{A}$.

The use of the the $k$-means grouping method requires prior declaration of the number of clusters. The greater the number of the distinguished clusters, the more likely a smaller number of elements (considered as industries in countries) in each of them, and thus potentially the easier the identification of the prevailing element in the form of an industry or country. With this in mind, as well as given the number of objects subject to the grouping process, thirteen was recognized as the optimal number of clusters in this classification procedure, which corresponds to the number of industries covered by the analysis. The clustering results for all sizes as a total (based on the means of ratios for all three size groups) are presented in Table 3 . The symbols of cluster elements contain two parts: the first part corresponds to the country, the other one - to the industry. Thus, for example the BE_AGR symbol refers to the agricultural sector in Belgium.

To identify the dominant effect, the number of different countries and the number of different industries occurring in each cluster were compared. Due to the fact that the total number of the countries (9) is smaller than the number of industries (13), the country effect may be slightly favoured. Inevitably, the number of different industries will usually exceed the number of different countries in a cluster. This preference, however, to some extent should be counteracted by the number of clusters corresponding to the number of industries and not to the number of countries. Thus, if the industry effect was the dominant one, then in the extreme case of no country impact, 
the internal structure of the clusters would coincide with the industrial classification.

In the analysed population, however, the dominance of any effect is not so obviously indicated by the contents of the clusters. Only in the case of one cluster (No. 13), the impact of domestic factors is certainly greater than that of the industrial ones, as the cluster contains only two elements from one country - Germany. A comparison of the number of prevailing items (different industries and different countries) in other clusters shows that only two of them can be considered as industry-dominated ones. These are clusters No. 3 and 6, dominated by the mining industry and the real estate sector, respectively.

In other clusters the number of different industries always slightly exceeds the number of different countries, reflecting the slightly greater impact of the country-specific factors on the capital structure. Table 4 shows the comparative list of the number of the prevailing elements in the form of industries and countries.

A similar $k$-means clustering procedure was also performed separately for each size group of enterprises in order to detect possible differences in the relative importance of the country and industry effect between small, medium and large firms. The various theories of capital structure do not answer the question about the way the industrial and national factors affect debt levels, depending on the firm size. Generally, according to the capital structure theories, the larger the firm size, the higher level of debt can be expected. Intuitively, however, one can hypothetically assume that as the firm size increases, the importance of country factors should decrease, in contrast to the industry factors. Such a tendency seems to be justifiable by the fact that large companies, more often than small ones, operate on global markets, and not just locally. As a result, they should be less susceptible to the influence of factors specific to the internal, domestic market. Thus, the role of other factors, including the industrial factors which act globally and affect all national markets in a similar way, should increase. The classification results of industries in countries for each size group are shown in Tables 5-7.

They show that due to the large preponderance of country-dominated clusters, the domestic factors prevail in all sized groups of enterprises. However, a closer look at the results reveals some more detailed regularities. For instance, only two clusters of an industrial nature were identified in the group of small enterprises. They are created mainly by the industries of information and communication, water supply, as well as trade, construction 
and administration. Definitely stronger industrial influences can be observed in the group of medium-sized companies, where as many as four of the thirteen clusters are of an industrial character. These clusters are gathered mainly around such industries as: manufacturing, trade, accommodation, construction and real estate. Against the hypothetical prediction, the industry effect is not the dominant one in the group of the large firms. Just as in the group of small entities, only two clusters demonstrate industrial features, specifically of the water supply industry, real estate and administration. In two other clusters it is not possible to identify the dominant factor due to the equal number of different industries and different countries. The remaining clusters are again dominated by the impact of domestic factors.

The evaluation of the clustering results' similarity between the size groups reveals their slight mutual resemblance. This is evidenced by the relatively low value of the adjusted Rand's measure presented in Table 8 significantly lower than 0.5 , which is interpreted as an indication of the moderate similarity of the classification results.

Despite small differences in the $\mathrm{R}_{\mathrm{AD}}$ values, it is worth noticing that the greatest degree of dissimilarity occurs between the clustering results for large and small companies. The generally low values of the Rand's measure indicate that the firm size has a significant impact on the grouping results of industries in countries.

Apart from the main conclusion drawn from the analysis of the grouping results, which refers to the prevalence of the country factors impact on corporate capital structure regardless of the firm size, in the analyzed population there can be certain characteristic countries and industries identified with stronger features determining the formation of clusters around them. As for the countries, one should mention the Netherlands, Spain, Germany, and Poland. The industries which mark their presence in clusters most include construction, administration, water supply and trade. It is worth searching for the reasons for which the abovementioned objects were so characteristically distinguished. In order to do so, one can analyse the expected means of the capital structure ratios for industries and countries. Figures 1 and 2 present the average values of the basic capital structure ratio, i.e. the debt to assets ratio (D/A) for all size groups in total. The vertical bars in the graphs represent $95 \%$ confidence limits.

One of the most characteristic regularities that can be read from the graphs is certainly the lowest level of debt in Polish firms. It is worth noting that such a situation is also typical for most other capital structure ratios under analysis. The low level of debt utilisation by Polish enterprises may be 
related to the high costs of debt service compared to other countries. In contrast, the most indebted companies occur in Germany, Austria and Portugal. The specificity of the administration and construction industry also corresponds to the relatively high levels of financial leverage.

\section{SUMMARY AND CONCLUSIONS}

To sum up the analytical results, it should be noted that the capital structure considerably depends on the country, where a firm operates, its industry, as well as its size. The capital structure diversity observed in these three sections is practically irrespective of the employed debt ratio, and therefore applies to both long-term debt and current liabilities. This is evidenced by the analysis of variance performed across countries, across industries and across size groups. Corporate capital structure, however, seems to be less dependent on time. In the case of this qualitative factor, the majority of the capital structure ratios show no significant differentiation, thus indicating the stability of the ratios over time.

With regard to the main objective of the research which was to compare the relative importance of the country and industry effects in capital structure and to detect potential differences in the strength of their interaction between different size groups of firms, the conclusions are as follows:

- the dominant effect in the analysed population is certainly the country effect, despite the fact that the study covers a group of countries with a relatively high degree of economic harmonization due to the integration process, which could suggest a decline in the importance of countryspecific factors and the growing importance of the industrial factors;

- country-specific factors are more important regardless of the firm size;

- the greater importance of the industry factors (although still lower than domestic factors) was observed in the group of medium-sized firms which can be explained by globalization affecting larger businesses more.

When comparing the relative importance of the country and industry factors on the corporate capital structure, it should be borne in mind that it is hardly possible to completely isolate these two effects from each other. This is due to the fact that each industry bears some characteristics of the country in which it operates. Similarly, the broadly defined debt of firms in a given country is also to some extent determined by the industrial structure of that country. Therefore it seems risky to attempt to precisely determine the extent to which industrial and country-specific factors affect the capital structure. 


\section{REFERENCES}

Almazan, A., Molina, C., Intra-Industry Capital Structure Dispersion, McCombs Research Paper Series, No. FIN-11-02, http://ssrn.com/abstract=292699, 2002.

Arabie, P., Boorman, S. A., Multidimensional Scaling of Measures of Distance between Partitions, "Journal of Mathematical Psychology", Vol. 10, No. 2, pp. 148-203, 1973.

Bancel, F., Mittoo, U., Cross-country Determinants of Capital Structure Choice: A Survey of European Firms, "Financial Management", Vol. 33, No. 4, pp. 103-132, 2004.

Bevan, A., Danbolt, J., Capital Structure and its Determinants in the UK - A Decompositional Analysis, University of Glasgow Working Paper, http://ssrn.com/abstract=233550, 2000.

Booth, L., Aivazian, V., Demirgüç-Kunt, A., Maksimovic, V., Capital Structure in Developing Countries, "Journal of Finance", Vol. 56, No. 1, pp. 87-130, 2001.

Bradley, M., Gregg, J., Han Kim, E., On the Existence of an Optimal Capital Structure: Theory and Evidence, "Journal of Finance", Vol. 39, No. 3, pp. 857-878, 1984.

Brounen, D., De Jong, A., Koedijk, K., Capital Structure Policies in Europe: Survey Evidence, "Journal of Banking and Finance", Vol. 30, No. 5, pp. 1409-1442, 2006.

Claessens, S., Djankov, S., Nenova, T., Corporate Risk around the World, [in:] Glick, R. Monerno, R., Spiegel, M. (eds.), Financial Crises in Emerging Markets, pp. 305-338. Cambridge University Press, Cambridge, 2001.

De Jong, A., Nguyen, T., Kabir, R., Capital Structure around the World: The Roles of Firmand Country-Specific Determinants, "Journal of Banking and Finance", Vol. 32, No. 9, pp. 1954-1969, 2008.

Demirgüç-Kunt, A., Maksimovic, V., Institutions, Financial Markets and Firm Debt Maturity, "Journal of Financial Economics", Vol. 54, No. 3, pp. 295-336, 1999.

Fan, J., Titman, S., Twite, G., An International Comparison of Capital Structure and Debt Maturity Choices, AFA 2005 Philadelphia Meetings, http://ssrn.com/abstract=423483, 2010.

Fisher, R. A., Statistical Methods for Research Workers. Oliver and Boyd, Edinburgh, 1954.

Fowkles, E. B., Mallows, C. L., A Method of Comparing Two Hierarchical Clusterings, "Journal of the American Statistical Association", Vol. 78, No. 383, pp. 553-569, 1983.

Frydenberg, S., Theory of Capital Structure - a Review [in:] Frihet og mangfold. Festskrift til Odd G. Arntzen, G., Fallan, L., Gustafsson, O., eds., Tapir Academic Press, Trondheim, Norway, http://ssrn.com/abstract=556631, 2011.

Giannetti, M., Do Better Institutions Mitigate Agency Problems? Evidence from Corporate Finance Choices, "Journal of Financial and Quantitative Analysis", Vol. 38, No. 1, pp. 185-212, 2003.

Goodman, L. A., Kruskal, W. H., Measures of Association for Cross Classifications. Springer-Veralg, Heidelberg, New York, 1980.

Gordon, A. D., A Review of Hierarchical Classification, "Journal of the Royal Statistical Society", series A, Vol. 150, No. 2, pp. 119-137, 1987.

Graham, J., Harvey, C., The Theory and Practice of Corporate Finance: Evidence from the Field, "Journal of Financial Economics", Vol. 60, No. 2-3, pp. 187-243, 2001.

Hall, G., Hutchinson, P., Michaelas, N., Determinants of the Capital Structures of European SMEs, "Journal of Business Finance and Accounting", Vol. 31, No. 5-6, pp. 711-728, 2004. 
Harris, M., Raviv, A., The Theory of Capital Structure, “Journal of Finance”, Vol. 46, No. 1, pp. 297-355, 1991.

Hennessy, Ch. A., Whited, T. M., How Costly is External Financing? Evidence from a Structural Estimation, Working Paper. University of Berkeley, 2006.

Hubert, L. J., Arabie, P., Comparing Partitions, “Journal of Classification”, Vol. 2, No. 1, pp. 286-288, 1985.

Jensen, M. C., Meckling, W. H., Theory of the Firm: Managerial Behavior, Agency Costs, and Ownership Structure, "Journal of Financial Economics", Vol. 3, No. 4, pp. 305-360, 1976.

Koralun-Bereźnicka, J., Międzynarodowe i międzysektorowe zróżnicowanie struktury kapitału przedsiębiorstw $w$ wybranych krajach Unii Europejskiej [International and Intersectional Diversity of Enterprises' Capital Structure in Chosen Countries of EU], [in:] Ostaszewski, J. (ed.), Dylematy ksztaltowania struktury kapitału w przedsiębiorstwie [Dilemmas of Capital Structure Creation in an Enterprise], pp. 199-209. Szkoła Główna Handlowa w Warszawie, Oficyna Wydawnicza, Warszawa, 2009.

Kurshev, A., Strebulaev, I. A., Firm Size and Capital Structure, AFA 2008 New Orleans Meetings Paper 2007, http://ssrn.com/abstract=686412, 2008.

Leibenstein, H., Allocative Efficiency versus X-efficiency, "American Economic Review", Vol. 56, Vo. 3, pp. 392-415, 1966.

Lööf, H., Dynamic Optimal Capital Structure and Technical Change, ZEW Discussion Paper, No. 03-06, 2003.

Maksimovic, V., Zechner, J., Agency, Debt and Product Industry Equilibrium, "Journal of Finance", Vol. 46, No. 5, pp. 1619-1643, 1991.

Modigliani, F., Miller, M. H., The Cost of Capital, Corporate Finance, and the Theory of Investment, "American Economic Review", Vol. 48, No. 3, pp. 261-297, 1958.

Najman, K., Charakterystyka mierników oceny podobieństwa wyników podziałów, Prace i Materiały Wydziału Zarządzania Uniwersytetu Gdańskiego. Finanse i informatyka w zarządzaniu, wybrane aspekty, No. 3, pp. 191-201, 2007.

Rajan, R. G., Zingales, L., What Do We Know about Capital Structure? Some Evidence from International Data, "Journal of Finance", Vol. 50, No. 5, pp. 1421-1460, 1995.

Rand, W. M., Objective Criteria for the Evaluation of Clustering Methods, "Journal of the American Statistical Association”, Vol. 66, No. 336, pp. 846-850, 1971.

Rohlf, F. J., Method of Comparing Classifications, "Annual Review of Ecology and Systematics", Vol. 5, pp. 101-113, 1974.

Shleifer, A., Vishny, R. W., Liquidation Values and Debt Capacity: A Market Equilibrium Approach, "Journal of Finance", Vol. 47, No. 4, pp. 1343-1365, 1992.

Shumway, T. G., Forecasting Bankruptcy More Accurately: A Simple Hazard Model, "Journal of Business", Vol. 74, No. 1, pp. 101-124, 2001.

Song, H.-S., Capital Structure Determinants: An Empirical Study of Swedish Companies, CESIS Electronic Working Paper Series No. 25, http://www.infra.kth.se/cesis/documents/ WP25.pdf, 2005.

Song, J., Philippatos, G., Have We Resolved Some Critical Issues Related to International Capital Structure? Empirical Evidence from the 30 OECD Countries, Working Paper, University of Tennessee, 2004. 
Titman, S., The Modigliani and Miller Theorem and Market Efficiency, Working paper, National Bureau of Economic Research, 2001.

Titman, S., Wessels, R., The Determinants of Capital Structure Choice, "Journal of Finance", Vol. 43, No. 1, pp. 1-19, 1988.

Wallace, D. L., A Method for Comparing Two Hierarchical Clusterings: Comment, "Journal of the American Statistical Association", Vol. 78, No. 383, pp. 569-576, 1983.

Wishart, D., K-Means Clustering with Outlier Detection, Mixed Variables and Missing Values, Proceedings of the German Classification Society, www.clustan.com, 2001.

Received: September 2013, revised: September 2015 


\section{APPENDIX}

Table 1

Industrial coverage of analysis according to NACE classification

\begin{tabular}{l|l|c}
\hline NACE & \multicolumn{1}{|c}{ Industry } & Symbol \\
\hline A & Agriculture, forestry and fishing & AGR \\
\hline B & Mining and quarrying & MIN \\
\hline $\mathrm{C}$ & Manufacturing & MNF \\
\hline $\mathrm{D}$ & Electricity, gas, steam and air conditioning supply & ELE \\
\hline $\mathrm{E}$ & Water supply; sewerage, waste management and remediation activities & WAT \\
\hline $\mathrm{F}$ & Construction & CST \\
\hline $\mathrm{G}$ & Wholesale and retail trade; repair of motor vehicles and motorcycles & TRD \\
\hline $\mathrm{H}$ & Transportation and storage & TRS \\
\hline $\mathrm{I}$ & Accommodation and food service activities & HOT \\
\hline $\mathrm{J}$ & Information and communication & INF \\
\hline L & Real esteta activities & RLE \\
\hline $\mathrm{M}$ & Professional, scientific and technical activities & PRF \\
\hline $\mathrm{N}$ & Administrative and support service activities & ADM \\
\hline
\end{tabular}

Source: author's calculation based on the NACE database

Table 2

Univariate significance tests, $\mathrm{p}=0.05 *$

\begin{tabular}{c|c|c|c|c|c|c|c|c}
\hline \multirow{2}{*}{ Ratio } & \multicolumn{10}{|c}{ Factor } \\
\cline { 2 - 9 } & \multicolumn{2}{|c|}{ Country } & \multicolumn{2}{|c}{ Industry } & \multicolumn{2}{c}{ Size } & \multicolumn{2}{c}{ Year } \\
\cline { 2 - 9 } & $\mathrm{F}$ & $\mathrm{p}$ & $\mathrm{F}$ & $\mathrm{p}$ & $\mathrm{F}$ & $\mathrm{p}$ & $\mathrm{F}$ & $\mathrm{p}$ \\
\hline $\mathrm{D} / \mathrm{A}$ & $\mathbf{1 3 9 . 3 0}$ & $\mathbf{0 . 0 0 0}$ & $\mathbf{4 4 . 1 3}$ & $\mathbf{0 . 0 0 0}$ & 2.687 & 0.068 & $\mathbf{1 0 . 8 2 0}$ & $\mathbf{0 . 0 0 0}$ \\
\hline $\mathrm{P} / \mathrm{A}$ & $\mathbf{2 4 9 . 0 0}$ & $\mathbf{0 . 0 0 0}$ & $\mathbf{2 9 . 0 2}$ & $\mathbf{0 . 0 0 0}$ & $\mathbf{8 9 . 3 2 0}$ & $\mathbf{0 . 0 0 0}$ & 1.421 & 0.173 \\
\hline $\mathrm{C} / \mathrm{A}$ & $\mathbf{4 0 . 7 6}$ & $\mathbf{0 . 0 0 0}$ & $\mathbf{6 7 . 1 6}$ & $\mathbf{0 . 0 0 0}$ & $\mathbf{1 0 6 . 9 0 0}$ & $\mathbf{0 . 0 0 0}$ & $\mathbf{2 . 1 5 0}$ & $\mathbf{0 . 0 2 3}$ \\
\hline $\mathrm{LC} / \mathrm{A}$ & $\mathbf{1 2 . 8 7}$ & $\mathbf{0 . 0 0 0}$ & $\mathbf{1 1 0 . 8 0}$ & $\mathbf{0 . 0 0 0}$ & $\mathbf{6 0 . 3 5 0}$ & $\mathbf{0 . 0 0 0}$ & 0.914 & 0.512 \\
\hline $\mathrm{SC} / \mathrm{A}$ & $\mathbf{1 7 0 . 1 0}$ & $\mathbf{0 . 0 0 0}$ & $\mathbf{4 1 . 3 1}$ & $\mathbf{0 . 0 0 0}$ & $\mathbf{7 8 . 7 7 0}$ & $\mathbf{0 . 0 0 0}$ & $\mathbf{5 . 0 6 2}$ & $\mathbf{0 . 0 0 0}$ \\
\hline $\mathrm{LL} / \mathrm{A}$ & $\mathbf{4 8 . 1 2}$ & $\mathbf{0 . 0 0 0}$ & $\mathbf{9 4 . 8 2}$ & $\mathbf{0 . 0 0 0}$ & $\mathbf{1 2 . 1 8 0}$ & $\mathbf{0 . 0 0 0}$ & 0.727 & 0.685 \\
\hline $\mathrm{SL} / \mathrm{A}$ & $\mathbf{5 5 . 3 8}$ & $\mathbf{0 . 0 0 0}$ & $\mathbf{1 7 2 . 1 0}$ & $\mathbf{0 . 0 0 0}$ & $\mathbf{4 . 7 9 7}$ & $\mathbf{0 . 0 0 8}$ & $\mathbf{7 . 1 1 8}$ & $\mathbf{0 . 0 0 0}$ \\
\hline
\end{tabular}

Note: * significant values of $\mathrm{F}$ and $\mathrm{p}$ in bold.

Source: author's calculations based on the BACH database 
Table 3

$K$-means grouping results of industries in countries for all size groups of firms in 2000-2009

\begin{tabular}{|c|c|c|c|c|c|c|c|c|c|c|c|c|}
\hline \multicolumn{13}{|c|}{ Cluster number } \\
\hline 1 & 2 & 3 & 4 & 5 & 6 & 7 & 8 & 9 & 10 & 11 & 12 & 13 \\
\hline BE_AGR & BE_MNF & BE_WAT & BE_HOT & BE_MIN & BE_RLE & AT_AGR & AT_MIN & AT_CST & AT_INF & BE_ELE & AT_WAT & DE_MIN \\
\hline BE_TRS & BE_CST & ES_MIN & ES_ELE & ES_AGR & DE_RLE & AT_TRS & AT_MNF & AT_TRD & AT_PRF & BE_PRF & AT_HOT & DE_PRF \\
\hline BE_ADM & BE_TRD & FR_MIN & ES_HOT & ES_WAT & FR_RLE & AT_RLE & AT_ELE & AT_ADM & DE_MNF & PL_AGR & IT_CST & \\
\hline FR_WAT & BE_INF & NL_MIN & ES_RLE & ES_TRS & PT_TRS & ES_CST & DE_ELE & DE_CST & DE_TRS & PL_ELE & PT_CST & \\
\hline FR_TRD & ES_MNF & NL_PRF & IT_ELE & ES_PRF & & ES_ADM & DE_WAT & DE_TRD & DE_HOT & PL_WAT & PT_RLE & \\
\hline FR_TRS & ES_TRD & & NL_AGR & FR_AGR & & IT_AGR & & DE_ADM & DE_INF & PL_RLE & PT_ADM & \\
\hline FR_HOT & ES_INF & & NL_MNF & PL_MIN & & IT_HOT & & FR_CST & FR_ELE & & & \\
\hline FR_INF & FR_MNF & & NL_TRD & PL_MNF & & PL_ADM & & IT_MNF & IT_TRS & & & \\
\hline FR_ADM & FR_PRF & & NL_TRS & PL_TRS & & & & IT_TRD & NL_WAT & & & \\
\hline IT_WAT & IT_MIN & & PT_PRF & PL_HOT & & & & IT_PRF & & & & \\
\hline IT_INF & IT_RLE & & & PL_INF & & & & IT_ADM & & & & \\
\hline NL_ELE & PL_CST & & & PL_PRF & & & & & & & & \\
\hline NL_CST & \begin{tabular}{|l|} 
PL_TRD \\
\end{tabular} & & & & & & & & & & & \\
\hline NL_HOT & PT_AGR & & & & & & & & & & & \\
\hline NL_INF & PT_MIN & & & & & & & & & & & \\
\hline NL_ADM & PT_MNF & & & & & & & & & & & \\
\hline \multicolumn{13}{|l|}{ PT_ELE } \\
\hline \multicolumn{13}{|l|}{ PT_WAT } \\
\hline \multicolumn{13}{|l|}{ PT_TRD } \\
\hline \multicolumn{13}{|l|}{ PT_HOT } \\
\hline PT_INF & & & & & & & & & & & & \\
\hline
\end{tabular}

Source: author's calculations based on the BACH database 
Table 4

The number of country and industry items in clusters of industries in countries for all size groups in 2000-2009

\begin{tabular}{|c|c|c|c|c|c|c|c|c|c|c|c|c|c|c|}
\hline \multirow{2}{*}{\multicolumn{2}{|c|}{$\begin{array}{l}\text { Country/ } \\
\text { industry }\end{array}$}} & \multicolumn{13}{|c|}{ Cluster number } \\
\hline & & 1 & 2 & 3 & 4 & 5 & 6 & 7 & 8 & 9 & 10 & 11 & 12 & 13 \\
\hline \multicolumn{2}{|c|}{ AT } & & & & & & & 3 & 3 & 3 & 2 & & 2 & \\
\hline \multicolumn{2}{|c|}{$\mathbf{B E}$} & 3 & 4 & 1 & 1 & 1 & 1 & & & & & 2 & & \\
\hline \multicolumn{2}{|c|}{ DE } & & & & & & 1 & & 2 & 3 & 4 & & & 2 \\
\hline \multicolumn{2}{|c|}{ ES } & & 3 & 1 & 3 & 4 & & 2 & & & & & & \\
\hline \multicolumn{2}{|c|}{ FR } & 6 & 2 & 1 & & 1 & 1 & & & 1 & 1 & & & \\
\hline \multicolumn{2}{|c|}{ IT } & 2 & 2 & & 1 & & & 2 & & 4 & 1 & & 1 & \\
\hline \multicolumn{2}{|c|}{ NL } & 5 & & 2 & 4 & & & & & & 1 & & & \\
\hline \multicolumn{2}{|c|}{ PL } & & 2 & & & 6 & & 1 & & & & 4 & & \\
\hline \multicolumn{2}{|c|}{ PT } & 5 & 3 & & 1 & & 1 & & & & & & 3 & \\
\hline \multicolumn{2}{|c|}{ AGR } & 1 & 1 & & 1 & 2 & & 2 & & & & 1 & & \\
\hline \multicolumn{2}{|c|}{ MIN } & & 2 & 3 & & 2 & & & 1 & & & & & 1 \\
\hline \multicolumn{2}{|c|}{ MNF } & & 4 & & 1 & 1 & & & 1 & 1 & 1 & & & \\
\hline \multicolumn{2}{|c|}{ ELE } & 2 & & & 2 & & & & 2 & & 1 & 2 & & \\
\hline \multicolumn{2}{|c|}{ WAT } & 3 & & 1 & & 1 & & & 1 & & 1 & 1 & 1 & \\
\hline \multicolumn{2}{|c|}{ CST } & 1 & 2 & & & & & 1 & & 3 & & & 2 & \\
\hline \multicolumn{2}{|c|}{ TRD } & 2 & 3 & & 1 & & & & & 3 & & & & \\
\hline \multicolumn{2}{|c|}{ TRS } & 2 & & & 1 & 2 & 1 & 1 & & & 2 & & & \\
\hline \multicolumn{2}{|c|}{ HOT } & 3 & & & 2 & & & 1 & & & 1 & & 1 & \\
\hline \multicolumn{2}{|c|}{ INF } & 4 & 2 & & & & & & & & 2 & & & \\
\hline \multicolumn{2}{|c|}{ RLE } & & 1 & & 1 & & 3 & 1 & & & & 1 & 1 & \\
\hline \multicolumn{2}{|c|}{ PRF } & & 1 & 1 & 1 & 2 & & & & 1 & 1 & 1 & & 1 \\
\hline \multicolumn{2}{|c|}{ ADM } & 3 & & & & & & 2 & & 3 & & & 1 & \\
\hline \multirow{2}{*}{$\begin{array}{l}\text { Number } \\
\text { of different }\end{array}$} & countries & 5 & 6 & 4 & 5 & 4 & 4 & 4 & 2 & 4 & 5 & 2 & 3 & 1 \\
\hline & industries & 9 & 8 & 3 & 8 & 6 & 2 & 6 & 4 & 5 & 7 & 5 & 5 & 2 \\
\hline \multicolumn{2}{|c|}{ The dominant effect } & C & $\mathbf{C}$ & I & $\mathbf{C}$ & C & $\mathbf{I}$ & $\mathrm{C}$ & $\mathrm{C}$ & C & C & $\mathrm{C}$ & C & $\mathrm{C}$ \\
\hline
\end{tabular}

Note: $\mathrm{C}$ - country effect, I - industry effect

Source: author's calculations based on the BACH database 
Table 5

The number of country and industry items in clusters of industries in countries for small firms in 2000-2009

\begin{tabular}{|c|c|c|c|c|c|c|c|c|c|c|c|c|c|c|}
\hline \multirow{2}{*}{\multicolumn{2}{|c|}{$\begin{array}{l}\text { Country / } \\
\text { industry }\end{array}$}} & \multicolumn{13}{|c|}{ Cluster number } \\
\hline & & 1 & 2 & 3 & 4 & 5 & 6 & 7 & 8 & 9 & 10 & 11 & 12 & 13 \\
\hline \multicolumn{2}{|c|}{ AT } & 2 & & & & & 2 & & & 3 & 3 & & 3 & \\
\hline \multicolumn{2}{|l|}{ BE } & & 2 & 4 & & 1 & 1 & & 3 & & & & & 2 \\
\hline \multicolumn{2}{|c|}{ DE } & 4 & & & & & 1 & & & 3 & 1 & & 3 & \\
\hline \multicolumn{2}{|l|}{ ES } & & & & 2 & 5 & 4 & & 1 & & & 1 & & \\
\hline \multicolumn{2}{|c|}{ FR } & & 3 & 4 & & & 1 & 4 & & & & & 1 & \\
\hline \multicolumn{2}{|l|}{ IT } & 2 & & & 2 & 2 & 1 & 3 & & 3 & & & & \\
\hline \multicolumn{2}{|c|}{$\mathbf{N L}$} & 9 & & & & 1 & & 1 & & & & & 1 & \\
\hline \multicolumn{2}{|c|}{ PL } & & & & & 4 & & & 5 & & & 2 & & 2 \\
\hline \multicolumn{2}{|c|}{ PT } & & 4 & & 4 & & & 2 & & 2 & & & & 1 \\
\hline \multicolumn{2}{|c|}{ AGR } & 1 & 1 & & 2 & 1 & 2 & & & & & 1 & & \\
\hline \multicolumn{2}{|c|}{ MIN } & 1 & & & 2 & 2 & & 1 & 1 & & & & 1 & 1 \\
\hline \multicolumn{2}{|c|}{ MNF } & 2 & & 1 & 2 & 2 & & & & 1 & & & 1 & \\
\hline \multicolumn{2}{|c|}{ ELE } & & 1 & & & 1 & 2 & 1 & 1 & & 1 & & 1 & 1 \\
\hline \multicolumn{2}{|c|}{ WAT } & 1 & & & & 1 & & 2 & 1 & & & & 3 & 1 \\
\hline \multicolumn{2}{|c|}{ CST } & 1 & & 1 & & 1 & 1 & 1 & & 4 & & & & \\
\hline \multicolumn{2}{|c|}{ TRD } & 1 & & 2 & 2 & 1 & & & & 3 & & & & \\
\hline \multicolumn{2}{|c|}{ TRS } & 2 & 1 & 2 & & 1 & 1 & & & & 1 & & 1 & \\
\hline \multicolumn{2}{|c|}{ HOT } & 1 & 3 & & & & 2 & & & & 1 & 1 & 1 & \\
\hline \multicolumn{2}{|c|}{ INF } & 3 & & & & 1 & & 3 & 2 & & & & & \\
\hline \multicolumn{2}{|c|}{ RLE } & & 2 & & & 1 & 2 & & & & 1 & 1 & & 1 \\
\hline \multicolumn{2}{|c|}{ PRF } & 3 & & 1 & & & & 1 & 3 & & & & & 1 \\
\hline \multicolumn{2}{|c|}{ ADM } & 1 & 1 & 1 & & 1 & & 1 & 1 & 3 & & & & \\
\hline \multirow{2}{*}{$\begin{array}{l}\text { Number of } \\
\text { different }\end{array}$} & countries & 4 & 3 & 2 & 3 & 5 & 6 & 4 & 3 & 4 & 2 & 2 & 4 & 3 \\
\hline & industries & 11 & 6 & 6 & 4 & 11 & 6 & 7 & 6 & 4 & 4 & 3 & 6 & 5 \\
\hline \multicolumn{2}{|c|}{ The dominant effect } & $\mathbf{I}$ & $\mathrm{C}$ & $\mathbf{C}$ & C & C & I & $\mathrm{C}$ & C & I & $\mathbf{C}$ & $\mathrm{C}$ & $\mathbf{C}$ & $\mathrm{C}$ \\
\hline
\end{tabular}

Source: author's calculations based on the BACH database 
Table 6

The number of country and industry items in clusters of industries in countries for medium firms in 2000-2009

\begin{tabular}{|c|c|c|c|c|c|c|c|c|c|c|c|c|c|c|}
\hline \multirow{2}{*}{\multicolumn{2}{|c|}{$\begin{array}{l}\text { Country/ } \\
\text { industry }\end{array}$}} & \multicolumn{13}{|c|}{ Cluster number } \\
\hline & & 1 & 2 & 3 & 4 & 5 & 6 & 7 & 8 & 9 & 10 & 11 & 12 & 13 \\
\hline \multicolumn{2}{|c|}{$\mathbf{A T}$} & & 1 & 1 & & 1 & 2 & 1 & & & & 2 & 3 & 2 \\
\hline \multicolumn{2}{|c|}{ BE } & 1 & 2 & & 3 & 1 & & & 3 & & 2 & & & 1 \\
\hline \multicolumn{2}{|c|}{ DE } & & & & & & 4 & 1 & & & & 2 & 4 & 1 \\
\hline \multicolumn{2}{|c|}{ ES } & 1 & 2 & 3 & & 1 & & & & 4 & 2 & & 1 & \\
\hline \multicolumn{2}{|c|}{ FR } & 1 & & & 4 & 1 & & & 3 & 1 & & 1 & & 1 \\
\hline \multicolumn{2}{|c|}{ IT } & 3 & 3 & 1 & 2 & & & 3 & & & & 1 & & \\
\hline \multicolumn{2}{|c|}{ NL } & 7 & 2 & & & & & & & 1 & & & 1 & \\
\hline \multicolumn{2}{|c|}{ PL } & 1 & & 1 & 1 & 1 & & & 2 & 2 & 5 & & & \\
\hline \multicolumn{2}{|c|}{ PT } & & 4 & 1 & 3 & 1 & & & & 2 & & 1 & & 1 \\
\hline \multicolumn{2}{|c|}{ AGR } & 1 & 2 & & & & & 1 & & 3 & 1 & & & \\
\hline \multicolumn{2}{|c|}{ MIN } & & & 1 & 1 & & 1 & & 1 & 3 & 1 & 1 & & \\
\hline \multicolumn{2}{|c|}{ MNF } & 1 & & 2 & & & 1 & 1 & 2 & 1 & & & 1 & \\
\hline \multicolumn{2}{|c|}{ ELE } & 2 & 1 & & & & 2 & & & & 2 & & 1 & \\
\hline \multicolumn{2}{|c|}{ WAT } & 1 & 1 & & 1 & & 1 & & 1 & & 2 & & 1 & 1 \\
\hline \multicolumn{2}{|c|}{ CST } & 1 & 2 & & 2 & & & 1 & & & & 3 & & \\
\hline \multicolumn{2}{|c|}{ TRD } & 1 & & 2 & 3 & & & 2 & & & & & 1 & \\
\hline \multicolumn{2}{|c|}{ TRS } & 3 & 1 & 1 & & & 1 & & 1 & & 1 & & & 1 \\
\hline \multicolumn{2}{|c|}{ HOT } & 1 & 1 & & & 5 & & & & & & & 1 & 1 \\
\hline \multicolumn{2}{|c|}{ INF } & 1 & & 1 & 3 & & & & 1 & 1 & & & 2 & \\
\hline \multicolumn{2}{|c|}{ RLE } & 1 & 1 & & & 1 & & & & 1 & 1 & & & 3 \\
\hline \multicolumn{2}{|c|}{ PRF } & & 1 & & 1 & & & & 2 & 1 & 1 & 1 & 2 & \\
\hline \multicolumn{2}{|c|}{ ADM } & 1 & 4 & & 2 & & & & & & & 2 & & \\
\hline \multirow{2}{*}{$\begin{array}{l}\text { Number of } \\
\text { different }\end{array}$} & countries & 6 & 6 & 5 & 5 & 6 & 2 & 3 & 3 & 5 & 3 & 5 & 4 & 5 \\
\hline & industries & 11 & 9 & 5 & 7 & 2 & 5 & 4 & 6 & 6 & 7 & 4 & 7 & 4 \\
\hline \multicolumn{2}{|c|}{ The dominant effect } & $\mathrm{C}$ & $\mathrm{C}$ & I & $\mathrm{C}$ & I & $\mathrm{C}$ & $\mathrm{C}$ & $\mathrm{C}$ & $\mathrm{C}$ & $\mathrm{C}$ & I & $\mathrm{C}$ & I \\
\hline
\end{tabular}

Source: author's calculations based on the BACH database 
Table 7

The number of country and industry items in clusters of industries in countries for large firms in 2000-2009

\begin{tabular}{|c|c|c|c|c|c|c|c|c|c|c|c|c|c|c|}
\hline \multirow{2}{*}{\multicolumn{2}{|c|}{$\begin{array}{l}\text { Country/ } \\
\text { industry }\end{array}$}} & \multicolumn{13}{|c|}{ Cluster number } \\
\hline & & 1 & 2 & 3 & 4 & 5 & 6 & 7 & 8 & 9 & 10 & 11 & 12 & 13 \\
\hline \multicolumn{2}{|c|}{ AT } & & & 1 & 5 & 4 & 1 & 2 & & & & & & \\
\hline \multicolumn{2}{|c|}{ BE } & 2 & 1 & 2 & & & & 1 & & 1 & & 3 & 1 & \\
\hline \multicolumn{2}{|c|}{ DE } & & 1 & & 2 & 2 & & & 1 & 1 & 5 & & & \\
\hline \multicolumn{2}{|c|}{ ES } & 2 & & 5 & 1 & & 2 & 2 & 1 & & 1 & & & \\
\hline \multicolumn{2}{|c|}{ FR } & 5 & & 1 & & & & 2 & 1 & 1 & & 1 & 1 & \\
\hline \multicolumn{2}{|l|}{ IT } & 4 & & 1 & & 1 & & 2 & & 4 & & 1 & & \\
\hline \multicolumn{2}{|c|}{ NL } & 3 & & 5 & & 1 & & & & & & 2 & & \\
\hline \multicolumn{2}{|c|}{ PL } & & & 3 & 1 & & & 1 & & & & 2 & 3 & 3 \\
\hline \multicolumn{2}{|c|}{ PT } & 3 & & 1 & 1 & & 1 & 1 & 2 & 2 & & & 1 & 1 \\
\hline \multicolumn{2}{|c|}{ AGR } & & & 1 & & & 1 & 1 & & & & 1 & 1 & 2 \\
\hline \multicolumn{2}{|c|}{ MIN } & 1 & & & 2 & 1 & & & & & 1 & 2 & 2 & \\
\hline \multicolumn{2}{|c|}{ MNF } & 2 & & 3 & 1 & & & & & & 1 & 2 & & \\
\hline \multicolumn{2}{|c|}{ ELE } & 1 & & 3 & 1 & & & & & & 2 & 1 & 1 & \\
\hline \multicolumn{2}{|c|}{ WAT } & 2 & 2 & & 1 & & 1 & 1 & & & & & 1 & \\
\hline \multicolumn{2}{|c|}{ CST } & 2 & & 2 & & 2 & & 1 & & 2 & & & & \\
\hline \multicolumn{2}{|c|}{ TRD } & 3 & & 3 & & 2 & & & & 1 & & & & \\
\hline \multicolumn{2}{|c|}{ TRS } & 1 & & 3 & & 1 & 1 & 1 & 1 & & 1 & & & \\
\hline \multicolumn{2}{|c|}{ HOT } & 1 & & 1 & 1 & 1 & 1 & 1 & & 1 & & 1 & & 1 \\
\hline \multicolumn{2}{|c|}{ INF } & 4 & & & 3 & & & 1 & & & & 1 & & \\
\hline \multicolumn{2}{|c|}{ RLE } & 1 & & & & & & 2 & 3 & & & & & 1 \\
\hline \multicolumn{2}{|c|}{ PRF } & & & 3 & 1 & & & & 1 & 1 & 1 & 1 & 1 & \\
\hline \multicolumn{2}{|c|}{ ADM } & 1 & & & & 1 & & 3 & & 4 & & & & \\
\hline \multirow{2}{*}{$\begin{array}{l}\text { Number of } \\
\text { different }\end{array}$} & countries & 6 & 2 & 8 & 5 & 4 & 3 & 7 & 4 & 5 & 2 & 5 & 4 & 2 \\
\hline & industries & 11 & 1 & 8 & 7 & 6 & 4 & 8 & 3 & 5 & 5 & 7 & 5 & 3 \\
\hline \multicolumn{2}{|c|}{ The dominant effect } & $\mathrm{C}$ & I & - & $\mathrm{C}$ & $\mathrm{C}$ & $\mathrm{C}$ & $\mathrm{C}$ & I & - & $\mathrm{C}$ & $\mathrm{C}$ & $\mathrm{C}$ & $\mathrm{C}$ \\
\hline
\end{tabular}

Source: author's calculations based on the BACH database

Table 8

Similarity of the classification results - adjusted Rand's measure $\left(\mathrm{R}_{\mathrm{AD}}\right)$

\begin{tabular}{c|c|c}
\hline Size & S & M \\
\hline M & 0,153 & \\
\hline $\mathrm{L}$ & 0,078 & 0,098 \\
\hline
\end{tabular}

Source: author's calculations based on the BACH database 


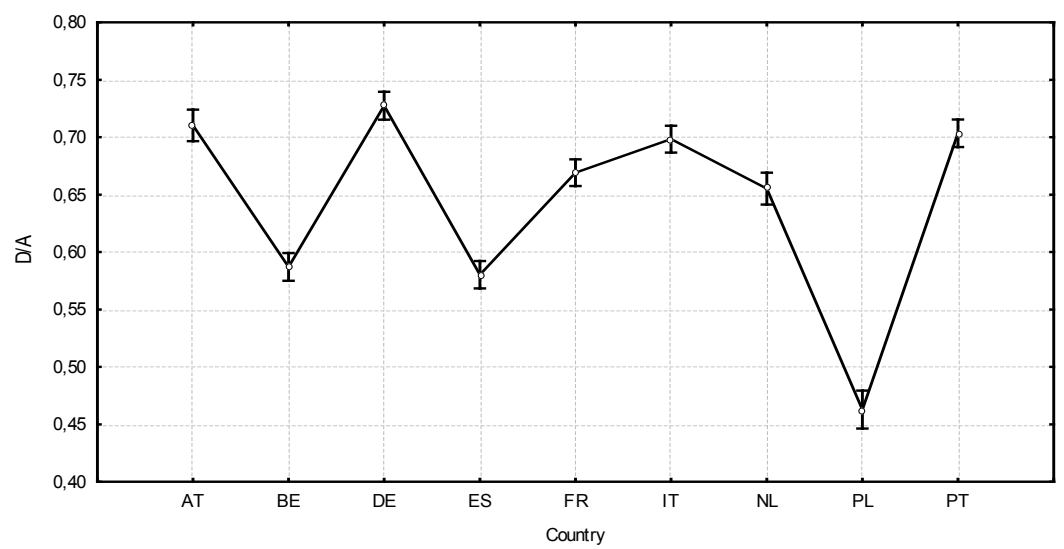

Figure 1. Expected means of the debt ratio (D/A) for countries Source: author's calculations based on the BACH database

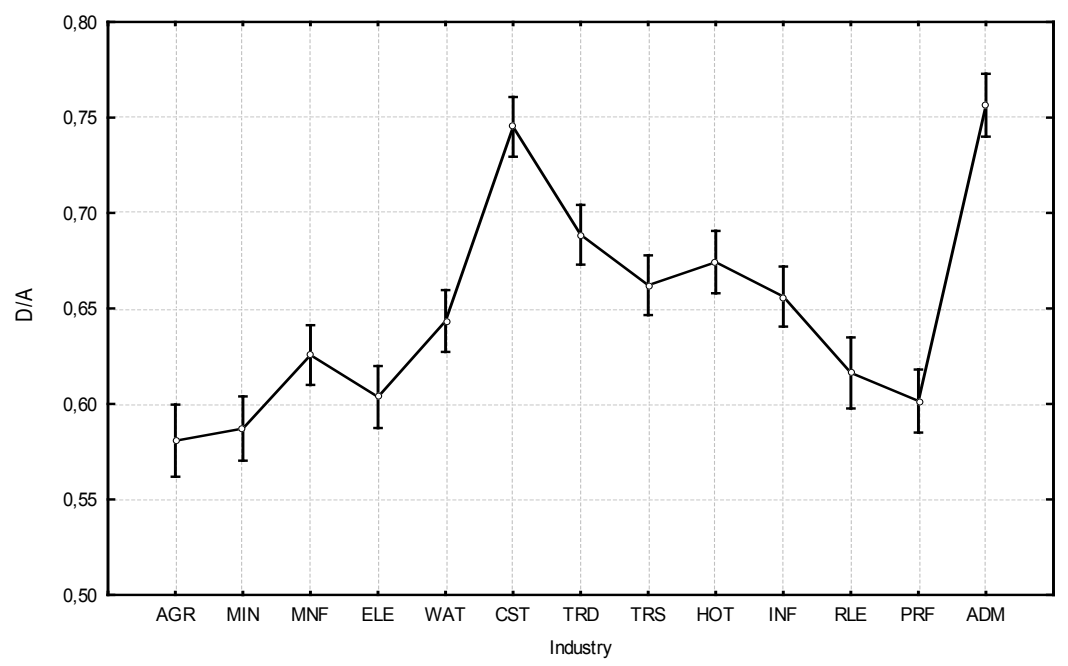

Figure 2. Expected means of the debt ratio (D/A) for industries

Source: author's calculations based on the BACH database 